\title{
Performans Pertumbuhan Kambing Boerawa di Village Breeding Centre, Desa Dadapan, Kecamatan Sumberejo, Kabupaten Tanggamus, Provinsi Lampung
}

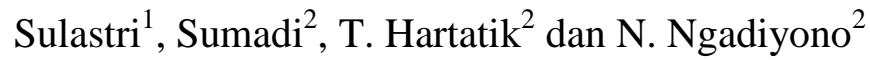 \\ ${ }^{1}$ Program Doktor pada Program Pascasarjana, Fakultas Peternakan, Universitas Gadjah Mada, \\ Yogyakarta, Indonesia \\ ${ }^{1}$ Jurusan Peternakan, Fakultas Pertanian, Universitas Lampung, Bandar Lampung, Indonesia \\ Jalan Prof. Sumantri Brojonegoro no.1, Gedongmeneng, Bandarlampung, 35145 \\ ${ }^{2}$ Fakultas Peternakan Universitas Gadjah Mada, Yogyakarta \\ Jalan Fauna No. 3 Bulaksumur, Yogyakarta \\ Email: sulastri_sekar@yahoo.com
}

\begin{abstract}
ABSTRAK
Penelitian dilakukan untuk mengevaluasi program persilangan grading up antara kambing Boer jantan dengan Peranakan Etawah (PE) betina di Village Breeding Centre (VBC) Desa Dadapan, Kecamatan Sumberejo, Kabupaten Tanggamus melalui performans pertumbuhan kambing PE, Boerawa grade 1 (BG1) dan Boerawa grade 2 (BG2). Penelitian dilakukan dengan metoda survei. Materi penelitian yang digunakan adalah recording performans pertumbuhan 525 ekor kambing PE, 450 kambing BG1, dan 175 kambing BG2 yang lahir pada 2009 sampai 2011 milik Kelompok Tani Karya Makmur III (anggota VBC). Peubah yang diamati meliputi berat badan dan ukuran-ukuran tubuh saat lahir, sapih, dan umur setahun. Data dianalisis dengan analisis keragaman Rancangan Acak Lengkap Pola Searah. Perbedaan mean diuji dengan Duncan Multiple Range Test. Rata-rata berat lahir kambing PE $(2,79 \pm 0,66 \mathrm{~kg})$ lebih rendah daripada BG1 $(3,22 \pm 0,64 \mathrm{~kg})$, namun BG1 tidak berbeda dengan BG2 $(3,02 \pm 0,89 \mathrm{~kg})$. Rata-rata berat sapih kambing PE $(18,28 \pm 0,053 \mathrm{~kg})$ lebih rendah daripada BG1 $(19,89 \pm 5,72 \mathrm{~kg})$ tetapi BG1 tidak berbeda dengan BG $2(19,67 \pm 1,54 \mathrm{~kg})$. Rata-rata berat setahunan kambing PE $(39,89 \pm 7,26 \mathrm{~kg})$ lebih rendah dari pada BG1 tetapi BG1 $(43,49 \pm 6,15 \mathrm{~kg})$ dan BG2 $(42,27 \pm 2,12 \mathrm{~kg})$ tidak berbeda. Pertambahan berat badan harian $(\mathrm{PBBH})$ prasapih absolut dan pascasapih absolut kambing $\mathrm{PE}, \mathrm{BG} 1$, dan BG2 tidak berbeda nyata. PBBH prasapih relatif kambing PE (7,95 $\pm 0,69 \%)$ lebih tinggi daripada BG1 $(3,57 \pm 0,14 \%)$ maupun BG2 $(4,77 \pm 0,64 \%)$, PBBH pascasapih relatif kambing PE $(0,60 \pm 1,31 \%)$ lebih tinggi daripada BG1 $(0,37 \pm 0,01 \%)$ maupun BG2 $(0,43 \pm 0,07 \%)$. Disimpulkan bahwa performans pertumbuhan kambing BG2 masih belum optimal.
\end{abstract}

Kata kunci: Peranakan Etawah, Boerawa grade 1, Boerawa grade 2, grading up, ukuran-ukuran tubuh

\section{Growth Performance of Boerawa Goat at Village Breeding Centre, Dadapan Village, Sumberejo Subdistrict, Tanggamus Regency, Lampung Province}

\begin{abstract}
The objective of research were to evaluate grading up program of Boer buck and Ettawa grade goat (EGG) doe at Village Breeding Centre (VBC) Dadapan village, Sumberejo subdistrict, Tanggamus regency by studying growth performance EGG, Boerawa grade 1 (BG1), and Boerawa grade 2 (BG2). Survey method was used in this research. Recording for growth performance of 525 heads EGG, 450 heads BG1, and 175 heads BG2 possessed by Karya Makmur III farmer group that was member of the VBC. Variables observed were body weight and body measurements at birth, weaning, and yearling. Data was analysed by analysis for variance of Completely Randomized Design for one way lay out. Difference of mean were analysed by Duncant's Multiple Range Test.
\end{abstract}


The average of birth weight of $E G G(2,79 \pm 0,66 \mathrm{~kg})$ were lower than that of $B G 1(3,22 \pm 0,64 \mathrm{~kg})$, however that of $B G 1$ were not different with $B G 2(3,02 \pm 0,89 \mathrm{~kg})$. The average of weaning weight of $E G G(18,28 \pm 0,053 \mathrm{~kg})$ were lower than that of $B G 1(19,89 \pm 5,72 \mathrm{~kg})$ however that of $B G 1$ were not different with that of $B G 2(19,67 \pm 1,54 \mathrm{~kg})$. The average of yearling weight of $E G G(39,89 \pm 7,26 \mathrm{~kg})$ were lower than that of $B G 1$ however that of $B G 1(43,49 \pm 6,15 \mathrm{~kg})$ were not different with $B G 2$ $(42,27 \pm 2,12 \mathrm{~kg})$. The absolute preweaning and postweaning average daily gain (ADG) of EGG, BGl, and $B G 2$ were not different. Relative preweaning $A D G$ of $E G G(7,95 \pm 0,69 \%)$ were higher $(P<0.05)$ than that of $B G 1(3,57 \pm 0,14 \%)$ and $B G 2(4,77 \pm 0,64 \%)$ however that of $B G 1$ were not different with BG2. Relative postweaning $A D G$ of $E G G(0,60 \pm 1,31 \%)$ were higher than that of $B G 1(0,37 \pm 0,01 \%)$ and $B G 2(0,43 \pm 0,07 \%)$. Average of postweaning $A D G$ of $B G 1$ and $B G 2$ were different $(P<0.05)$. Its conclusion that growth performance of BG2 have not optimum.

Key words: Ettawa grade goat, Boerawa grade 1, Boerawa grade 2, grading up, bodyweight, body measurements

\section{PENDAHULUAN}

Kambing Boerawa merupakan kambing hasil persilangan antara kambing Boer jantan dengan Peranakan Etawah (PE) betina yang dikembangkan di Kabupaten Tanggamus, Provinsi Lampung mulai tahun 2002. Persilangan tersebut dimaksudkan untuk memperoleh kambing silangan yang memiliki proporsi genetik kambing Boer tinggi dan PE rendah melalui grading up. Kambing silangan dengan proporsi genetik kambing Boer dan genetik PE tertentu yang menghasilkan performans terbaik selanjutnya akan diberi nama Saburai.

Grading up merupakan persilangan antara kambing lokal betina dengan kambing impor jantan dengan tujuan mengubah bangsa kambing betina kearah bangsa pejantannya. Pada tahapan pertama grading up diperoleh kambing silangan dengan proporsi genetik kambing lokal dan impor masing-masing 50\%. Pada tahap kedua, dihasilkan kambing silangan grade 1 (filial 1) dengan proporsi genetik kambing impor $75 \%$ dan lokal 25\%. Pada tahap kedua diperoleh kambing silangan grade 2 dengan proporsi genetik kambing impor $87,5 \%$ dan lokal $12,5 \%$, silangan grade 3 mengandung proporsi genetik kambing impor 93,75\% dan 6,25\% kambing lokal (Hardjosubroto, 1994).

Hasil persilangan Boer jantan dengan PE betina dinamakan Boerawa grade 1 (BG1) dan hasil persilangan antara Boer jantan dengan BG1 menghasilkan silangan dengan nama Boerawa grade 2 (BG2). Permasalahannya, performans pertumbuhan dan konformasi tubuh kambing BG2 ternyata lebih rendah daripada BG1.

Berdasarkan uraian tersebut dilakukan penelitian tentang performans pertumbuhan kambing PE, BG1, dan BG2 dari lahir sampai umur setahun untuk mengevaluasi perkembangan program grading up ditinjau dari segi pertumbuhan.

\section{MATERI DAN METODE}

Penelitian dilakukan di Village Breeding Centre (VBC) Desa Dadapan, Kecamatan Sumberejo, Kabupaten Tanggamus, Provinsi Lampung dengan metode survei mulai 9 Januari sampai April 2012.

Materi penelitian yang digunakan adalah recording pertumbuhan 525 ekor kambing PE, 450 ekor kambing BG1, dan 175 ekor kambing BG2 yang lahir dari tahun 2009 sampai dengan 2011 milik kelompok Tani Karya Makmur III di VBC Pekon Dadapan, Kecamatan Gisting, Kabupaten Tanggamus, Provinsi Lampung.

Variabel yang diamati meliputi sifat-sifat pertumbuhan (berat lahir, berat sapih, berat setahunan) dan ukuran-ukuran tubuh (panjang badan, tinggi badan, lingkar dada, tinggi kemudi, panjang telinga, dan lebar telinga) saat lahir, sapih, dan umur setahun. Pengukuran dilakukan oleh peternak kambing setiap umur kambing 
meningkat 3 bulan sehingga terdapat catatan pertumbuhan umur 0 hari, 3 bulan, 6 bulan, 9 bulan, dan 12 bulan sesuai dengan rekomendasi dari Dinas Peternakan dan Kesehatan Hewan Provinsi Lampung.

Penimbangan untuk memperoleh berat lahir, sapih, dan setahunan dilakukan oleh peternak dengan menggunakan timbangan gantung merk Shelter kapasitas $120 \mathrm{~kg}$ dengan ketelitian 0,01 kg. Panjang badan, lebar dada, dalam dada, tinggi pinggul diukur dengan menggunakan tongkat ukur yang terbuat dari kayu dan dilengkapi dengan pita ukur merk Butterfly dengan kapasitas $300 \mathrm{~cm}$ ketelitian $0,01 \mathrm{~cm}$. Lingkar dada diukur dengan menggunakan pita ukur merk Rondho dengan kapasitas $1.000 \mathrm{~cm}$ dengan ketelitian $0,01 \mathrm{~cm}$.

Pengukuran variabel-variabel tersebut dapat dilakukan dengan cara sesuai rekomendasi Sumadi dan Prihadi (1997) sebagai berikut:

a. Berat lahir (BL) diukur dengan menggunakan timbangan gantung dengan cara menimbang cempe sesaat setelah lahir dengan batas maksimal penimbangan 24 jam setelah cempe dilahirkan

b. Berat sapih (BS) diperoleh dengan cara menimbang cempe sesaat setelah disapih dari induknya pada umur 3 sampai 4 bulan.

c. Berat setahunan (BSt) diperoleh dengan cara menimbang kambing pada umur sekitar 12 bulan.

d. Panjang badan (PB) absolut, diukur dengan menggunakan tongkat ukur dengan posisi kambing berdiri tegak dan keempat kaki kambing membentuk empat persegi panjang. Pengukuran dilakukan dari ujung sendi bahu ke bungkul tulang duduk

e. Tinggi badan (TB), diukur dengan menggunakan tongkat ukur dari atas tanah tempat kambing berdiri sampai dengan titik tertinggi pada gumba, pada tulang rusuk ketiga dan keempat.

f. Tinggi pinggul (TP), diukur dengan menggunakan tongkat ukur, dari atas permukaan tanah tempat kambing berdiri sampai titik tertinggi tulang kemudi.

g. Lingkar dada (LD), diukur dengan menggunakan pita ukur dengan cara melingkarkan pita ukur pada dada di belakang siku.

h. Panjang telinga (PT), diukur dengan menggunakan pita ukur tepat di bagian tengah telinga dengan mengukur jarak antara pangkal telinga dengan ujung telinga.

i. Lebar telinga (LT), diukur dengan menggunakan pita ukur pada bagian telinga terlebar dengan mengukur jarak antar tepi telinga.

Pertambahan berat badan harian $(\mathrm{PBBH})$ prasapih dan pasca sapih relatif dihitung dengan rumus sebagai berikut:

$\mathrm{PBBH}$ prasapih relatif $(\%)=$

$\left(\left(\frac{\mathrm{BST}-\mathrm{BLT}}{\mathrm{US}}\right) / \mathrm{BL}\right) \times 100 \%$

PBBH pascasapih relatif $(\%)=$

$\left(\left(\frac{\mathrm{BStT}-\mathrm{BST}}{\mathrm{TW}}\right) / \mathrm{BS}\right) \times 100 \%$

Keterangan:

$\mathrm{PBBH}=$ pertambahan berat badan harian

BLT = berat lahir terkoreksdi

BST = berat sapih terkoreksi

$\mathrm{BStT}=$ berat setahunan terkoreksi

US = umur sapih

TW = tenggang waktu antara umur setahun dengan umur sapih

Hasil pengamatan ditabulasi sesuai tahapan umur (lahir, sapih, dan setahun) diuji dengan analisis keragaman Rancangan Acak Lengkap Pola Searah. Perbedaan mean diuji dengan Duncan Multiple Range Test sesuai rekomendasi Steel and Torrie (1991).

\section{HASIL DAN PEMBAHASAN}

\section{Berat Lahir dan Ukuran-Ukuran Tubuh Saat Lahir}

Rata-rata berat lahir kambing BG1 $(3,42 \mathrm{~kg})$ tertinggi diikuti kambing $\mathrm{BG} 2$ yaitu $3,32 \mathrm{~kg}$, dan terendah kambing $\mathrm{PE}$ $(2,79 \mathrm{~kg})$ sebagaimana terdapat pada Tabel 1 . 
Berat lahir dan ukuran-ukuran tubuh saat lahir pada cempe Boerawa G1 tertinggi dibandingkan kambing BG2 dan PE, Hal tersebut merupakan hasil pewarisan yang tinggi dari kambing Boer sebagai bangsa dengan berat badan dan ukuran-ukuran tubuh yang tinggi. Rata-rata berat lahir kambing Boer 3,4 sampai 4,0 kg, (LeiteBrowning, 2006). Kambing Boer merupakan satu-satunya kambing tipe pedaging di dunia yang pertumbuhannya cepat dan telah teregistrasi selama lebih 65 tahun (Shipley and Shipley, 2005). Kambing Boer memiliki kemampuan beradaptasi dengan baik pada berbagai kondisi iklim, sistem produksi dan tipe pastura (Erasmus, 2000).

Berat lahir dan ukuran-ukuran tubuh saat lahir cempe BG1 hasil penelitian ini lebih tinggi daripada cempe PE. Hal tersebut menunjukkan keberhasilan program persilangan yang dilakukan di Provinsi Lampung dalam upaya meningkatkan performans pertumbuhan kambing $\mathrm{PE}$ melalui persilangan dengan Boer jantan.

Keberhasilan program persilangan pada BG1 ternyata tidak terjadi pada BG2. Berat lahir dan ukuran-ukuran tubuh cempe Boerawa G2 ternyata lebih rendah daripada berat lahir cempe BG1. Hal tersebut dapat dijelaskan melalui pendekatan pejantan dan betina yang merupakan tetua cempe BG2.

Boer jantan yang dikawinkan dengan PE betina untuk menghasilkan BG1 berbeda dengan pejantan yang digunakan untuk menghasilkan BG2. Perbedaan individuindividu yang digunakan sebagai pejantan mengakibatkan perbedaan potensi genetik yang terdapat pada keturunannya. Individuindividu Boer jantan untuk menghasilkan BG1 seluruhnya dipelihara oleh Instalasi Produksi Mani Beku (IPMB) Terbanggi Besar dan spermanya diolah dalam bentuk semen beku sehingga tidak pernah mengawini kambing PE secara langsung.

Boer jantan untuk menghasilkan BG2 sebagian besar dalam bentuk semen beku dan sebagian berupa pejantan melalui kawin secara alamiah. Sembilan ekor Boer jantan dipinjamkan oleh Dinas Peternakan dan Kesehatan Hewan Provinsi Lampung pada kelompok-kelompok ternak di Kabupaten Tanggamus yang merupakan Village Breeding Centre (VBC) kambing Boerawa. Berat lahir cempe Boerawa BG1 hasil perkawinan secara inseminasi buatan lebih tinggi daripada cempe BG2 yang dikawinkan secara alamiah. Hal tersebut disebabkan adanya seleksi melalui uji zuriat yang dilakukan pada pejantan Boer yang akan diambil spermanya. Uji tersebut belum dilakukan pada kambing Boer yang digunakan untuk mengawini kambing BG1 betina untuk menghasilkan BG2. Kambing Boer jantan yang terbukti memiliki potensi genetik tinggi selanjutnya diambil spermanya untuk diolah menjadi semen beku di IPMB Terbanggi Besar, Kabupaten Lampung Tengah. Uji zuriat merupakan pengujian terhadap potensi genetik pejantan berdasarkan performans anak-anaknya (Hardjosubroto, 1994).

Berat lahir dan ukuran-ukuran tubuh saat lahir pada cempe BG2 lebih rendah daripada BG1 karena PE betina yang dikawinkan dengan Boer jantan memiliki berat lahir yang sudah stabil. Berat lahir yang stabil tersebut merupakan ekspresi keragaman henetik aditif dan tidak banyak dipengaruhi oleh keragaman genetik non aditif. Keragaman genetik aditif suatu sifat tersebut sangat penting dalam pemuliabiakan ternak karena diwariskan pada keturunannya dan tanggap terhadap seleksi sehingga keragaman berat lahir dapat diprediksi karena tidak banyak mengalami perubahan. Keragaman berat lahir kambing PE sudah stabil karena kambing PE merupakan hasil perkawinan interse antara kambing $\mathrm{PE}$ dengan kambing PE. Perkawinan interse mengakibatkan semakin rendahnya pengaruh keragaman non aditif sehingga performans ternak yang terlihat dan terukur merupakan ekspresi dari pengaruh keragaman genetik aditif. Keragaman genetic non aditif mengakibatkan ketidakstabilan performans karena tidak diwariskan pada keturunannya dan tidak tanggap terhadap seleksi (Hardjosubroto, 1994). 
Tabel 1. Rata-rata berat badan dan ukuran-ukuran tubuh saat lahir pada kambing BG1, BG2, dan PE

\begin{tabular}{lcrc}
\hline \hline \multicolumn{1}{c}{ Sifat } & \multicolumn{3}{c}{ Bangsa Kambing } \\
\cline { 2 - 4 } & PE & BG1 & BG2 \\
\hline Berat lahir $(\mathrm{kg})$ & $2,79 \pm 0,66^{\mathrm{a}}$ & $3,22 \pm 0,64^{\mathrm{b}}$ & $3,02 \pm 0,89^{\mathrm{b}}$ \\
Tinggi badan $(\mathrm{cm})$ & $24,59 \pm 0,21^{\mathrm{a}}$ & $28,12 \pm 0,83^{\mathrm{b}}$ & $28,03 \pm 0,46^{\mathrm{b}}$ \\
Panjang badan $(\mathrm{cm})$ & $25,57 \pm 1,06^{\mathrm{a}}$ & $25,83 \pm 1,47^{\mathrm{b}}$ & $25,72 \pm 0,66^{\mathrm{b}}$ \\
Lingkar dada $(\mathrm{cm})$ & $27,85 \pm 0,96^{\mathrm{a}}$ & $28,10 \pm 0,82^{\mathrm{b}}$ & $28,05 \pm 0,22^{\mathrm{b}}$ \\
Tinggi pinggul $(\mathrm{cm})$ & $25,77 \pm 0,67^{\mathrm{a}}$ & $27,81 \pm 0,47^{\mathrm{b}}$ & $26,02 \pm 0,25^{\mathrm{c}}$ \\
Panjang telinga $(\mathrm{cm})$ & $12,41 \pm 0,35^{\mathrm{a}}$ & $10,51 \pm 1,29^{\mathrm{b}}$ & $10,52 \pm 0,91^{\mathrm{b}}$ \\
Lebar telinga $(\mathrm{cm})$ & $5,75 \pm 1,46^{\mathrm{a}}$ & $7,01 \pm 0,82^{\mathrm{b}}$ & $7,01 \pm 0,23^{\mathrm{b}}$ \\
\hline
\end{tabular}

Keterangan: Superskrip dengan huruf yang berbeda pada kolom yang berbeda menunjukkan perbedaan nyata $(\mathrm{P}<0,05)$

Tabel 2. Rata-rata berat badan dan ukuran-ukuran tubuh saat sapih pada kambing PE, BG1, dan BG2 di Provinsi Lampung

\begin{tabular}{lccc}
\hline \hline Sifat & \multicolumn{3}{c}{ Bangsa Kambing } \\
\cline { 2 - 4 } & PE & BG1 & BG2 \\
\hline Berat sapih $(\mathrm{kg})$ & $18,28 \pm 0,053^{\mathrm{a}}$ & $19,89 \pm 5,72^{\mathrm{b}}$ & $19,67 \pm 1,54^{\mathrm{b}}$ \\
Tinggi badan(cm) & $50,74 \pm 2,08^{\mathrm{a}}$ & $50,60 \pm 1,20^{\mathrm{a}}$ & $50,60 \pm 1,06^{\mathrm{a}}$ \\
Panjang badan $(\mathrm{cm})$ & $46,94 \pm 1,68^{\mathrm{a}}$ & $47,97 \pm 1.80^{\mathrm{b}}$ & $47.86 \pm 1,02^{\mathrm{b}}$ \\
Lingkar dada $(\mathrm{cm})$ & $39,25 \pm 1,58^{\mathrm{a}}$ & $43,75 \pm 1,60^{\mathrm{b}}$ & $44,02 \pm 1,09^{\mathrm{c}}$ \\
Tinggi pinggul $(\mathrm{cm})$ & $54,95 \pm 2,82^{\mathrm{a}}$ & $54,84 \pm 1,43^{\mathrm{a}}$ & $54,77 \pm 1,34^{\mathrm{a}}$ \\
Panjang telinga (cm) & $16,55 \pm 1,90^{\mathrm{a}}$ & $13,50 \pm 1,30^{\mathrm{b}}$ & $13,53 \pm 1,79^{\mathrm{b}}$ \\
\hline
\end{tabular}

Keterangan: Superskrip dengan huruf yang berbeda pada kolom yang berbeda menunjukkan perbedaan nyata $(\mathrm{P}<0,05)$

Kambing BG1 merupakan hasil persilangan antara Boer jantan dan PE yang dikembangkan di Kabupaten Tanggamus, Provinsi Lampung mulai tahun 2002. Kambing BG1 tersebut belum mencapai performans yang stabil karena tidak pernah dilakukan program perkawinan interse (perkawinan BG1 jantan dan BG1 betina). Kambing BG1 betina langsung dikawinkan kembali dengan kambing Boer jantan.

Performans pertumbuhan BG1 betina yang belum stabil menghasilkan BG2 dengan berat lahir dan ukuran-ukuran tubuh saat lahir yang lebih rendah daripada BG1. Selama proses grading up tersebut, seharusnya performans pertumbuhan kambing Boerawa menunjukkan peningkatan seiring dengan meningkatnya kandungan genetik kambing Boer dalam kambing Boerawa.
Rata-rata berat lahir cempe Boerawa baik BG1 maupun BG2 hasil penelitian ini lebih rendah daripada hasil penelitian Nasich (2011) maupun Nurgiartiningsih et al. (2006) pada tipe kelahiran tunggal walaupun masing-masing masih lebih tinggi daripada $3,0 \mathrm{~kg}$, namun masih dalam kisaran hasil penelitian Nasich (2011) pada kelompok kambing Boerawa jantan dan betina. Nasich (2011) melaporkan bahwa rata-rata berat lahir cempe Boerawa yang dilahirkan dalam tipe kelahiran tunggal $3,56 \mathrm{~kg}$, kembar dua 2,88 $\mathrm{kg}$, kembar tiga $1,40 \mathrm{~kg}$, Nurgiartiningsih et al. (2006) melaporkan bahwa berat lahir cempe Boerawa pada kelahiran tunggal $3,26 \mathrm{~kg}$, kembar dua $3,10 \mathrm{~kg}$, kembar tiga $2,51 \mathrm{~kg}$. Menurut Nasich (2011), rata-rata berat lahir cempe jantan $3,26 \mathrm{~kg}$ dan cempe betina $3,09 \mathrm{~kg}$. 
Rata-rata berat lahir cempe PE hasil penelitian ini $(2,79 \mathrm{~kg})$. Beberapa peneliti melaporkan bahwa rata-rata berat lahir cempe PE betina $2,7 \mathrm{~kg}$ dan jantan $3,0 \mathrm{~kg}$ (Luminto, 2005), 3,47 kg pada tipe kelahiran tunggal, 3,00 kg pada tipe kelahiran kembar dua, 3,34 kg pada jantan dan 3,12 kg pada betina (Kurnianto et al., 2007).

Perbedaan berat lahir kambing Boerawa maupun PE hasil penelitian ini dengan hasil penelitian lain disebabkan oleh adanya perbedaan genetik kambing Boer dan PE yang menghasilkan kambing Boerawa serta perbedaan manajemen pemeliharaan di lokasi yang berbeda. Perbedaan berat lahir ternak pada bangsa yang sama dipengaruhi oleh manajemen pemeliharaan, perbedaan potensi genetik pejantan, dan kondisi lingkungan (Mahmilia et al., 2010; Bharathidasan et al., 2009; Thiruvenkadan et al., 2008).

\section{Berat Sapih dan Ukuran-Ukuran Tubuh Saat Sapih}

Hasil penelitian menunjukkan bahwa berat sapih dan ukuran-ukuran tubuh saat sapih kambing BG1 lebih tinggi daripada PE. Hal tersebut memperlihatkan keberhasilan persilangan antara Boer jantan dengan PE betina. Persilangan antara dua bangsa ternak bertujuan untuk menyatukan sifat-sifat unggul yang terdapat pada kedua bangsa kedalam satu bangsa silangan (Hardjosubroto, 1994).

Berat sapih dan ukuran-ukuran tubuh saat sapih cempe BG2 ternyata sama dengan pada berat lahir yang lebih lebih rendah daripada BG1 walaupun masih lebih tinggi daripada berat sapih cempe PE. Hasil persilangan antara kambing PE dengan Boer menghasilkan berat sapih yang lebih tinggi daripada PE namun lebih rendah daripada Boer. Rata-rata berat sapih kambing Boer adalah 24,0 kg (Barry and Godke, 2005), 20 sampai $25 \mathrm{~kg}$ (Greyling, 2000).

Berat sapih dan ukuran-ukuran tubuh cempe BG2 lebih rendah daripada BG1 karena BG1 betina yang dikawinkan dengan Boer jantan sama dengan pada berat lahir yaitu sama-sama memiliki performans yang belum stabil karena belum dilakukan interse antara BG1 dengan BG1.

Perkawinan interse dilakukan untuk mengeliminir pengaruh heterosis yang merupakan aksi gen bukan aditif. Keunggulan performans yang terlihat pada performans sekelompok ternak karena aksi heterosis tidak diwariskan pada keturunannya dan akan hilang apabila dikawinkan dengan ternak F1 (Warwick et al., 1990).

Heterosis merupakan kejadian dalam suatu persilangan yang ditandai dengan tingginya performans ternak silangan bahkan melampaui rata-rata performans kedua tetuanya. Penyebab heterosis belum diketahui dengan pasti tetapi diduga merupakan aksi gen non aditif yang dapat mengakibatkan terjadinya dominasi, over dominasi, dan epistasis.

Pada perkawinan interse (individu F1 dengan $\mathrm{F} 1$ atau individu F2 dengan F2), maka setiap generasi mengalami penurunan koefisien heterosis sebesar $50 \%$. Penurunan heterosis dapat dirumuskan dengan rumus $\% \mathrm{H}_{\mathrm{F} 2}=1 / 2 \mathrm{dy}^{2}=1 / 2 \mathrm{H}_{\mathrm{F} 1}$. Apabila $\mathrm{H}_{\mathrm{F} 2}$ tidak sebesar $1 / 2 \mathrm{H}_{\mathrm{F} 1}$ berarti masih ada pengaruh epistasis. Apabila perkawinan interse diteruskan, maka heterosis akan hilang (Hardjosubroto, 1994).

Rata-rata berat sapih kambing BG1 dan BG2 hasil penelitian ini masing-masing $19,89 \mathrm{~kg}$ dan $19,67 \mathrm{~kg}$. Rata-rata berat sapih (umur sapih sekitar 3 bulan) tersebut berbeda dengan hasil penelitian lain bahwa cempe BG1 kelahiran tunggal $16,4 \mathrm{~kg}$, kembar dua 12,47 kg, kembar tiga 10,511 kg dan (Nasich, 2011).

Berat sapih kambing PE adalah 16,30 kg (Sulastri dan Sumadi, 2004), 16,813 kg yang mendapat pakan tradisional dan 18,063 $\mathrm{kg}$ yang mendapat pakan rasional (Dakhlan et al., 2009), 9,00 kg pada cempe jantan dan 8,97 kg (Kurnianto et al., 2007). 
Tabel 3. Rata-rata berat badan dan ukuran-ukuran tubuh saat setahunan pada bangsa kambing PE, BG1, dan BG2 di Provinsi Lampung

\begin{tabular}{lccc}
\hline \hline Sifat & \multicolumn{3}{c}{ Bangsa Kambing } \\
\cline { 2 - 4 } & PE & BG1 & BG2 \\
\hline Berat setahunan $(\mathrm{kg})$ & $39,89 \pm 7,26^{\mathrm{a}}$ & $43,49 \pm 6,15^{\mathrm{b}}$ & $42,27 \pm 2,12^{\mathrm{c}}$ \\
Tinggi badan $(\mathrm{cm})$ & $61,66 \pm 1,51^{\mathrm{a}}$ & $65,88 \pm 2,37^{\mathrm{b}}$ & $61,79 \pm 1,19^{\mathrm{c}}$ \\
Panjang badan (cm) & $58,71 \pm 1,57^{\mathrm{a}}$ & $67,31 \pm 2,57^{\mathrm{b}}$ & $58.01 \pm 1,01^{\mathrm{c}}$ \\
Lingkar dada (cm) & $62,62 \pm 2,10^{\mathrm{a}}$ & $70,13 \pm 2,98^{\mathrm{b}}$ & $67,78 \pm 1,12^{\mathrm{c}}$ \\
Tinggi pinggul (cm) & $69,96 \pm 2,63^{\mathrm{a}}$ & $53,68 \pm 1,98^{\mathrm{b}}$ & $52,56 \pm 2,03^{\mathrm{b}}$ \\
Panjang telinga (cm) & $20,22 \pm 1,68^{\mathrm{a}}$ & $18,89 \pm 1,55^{\mathrm{b}}$ & $18,79 \pm 1,56^{\mathrm{b}}$ \\
Lebar telinga (cm) & $10,56 \pm 1,01^{\mathrm{a}}$ & $8,00 \pm 0,29^{\mathrm{b}}$ & $8,00 \pm 0,23^{\mathrm{b}}$ \\
\hline
\end{tabular}

Keterangan: Superskrip dengan huruf yang berbeda pada kolom yang berbeda menunjukkan perbedaan nyata $(\mathrm{P}<0,05)$

Tabel 4. Pertambahan berat badan harian absolut dan relatif

\begin{tabular}{lllll}
\hline \hline Sifat & \multicolumn{3}{c}{ Kambing } & Uji F \\
\cline { 2 - 4 } $\begin{array}{llll}\text { PBBH prasapih } \\
\text { absolut (kg) }\end{array}$ & $0,18 \pm 0,03^{\mathrm{a}}$ & $0,17 \pm 0,02^{\mathrm{a}}$ & $0,18 \pm 0,01^{\mathrm{a}}$ & $\mathrm{P}>0,05$ \\
$\quad$ relatif (\%) & $7,95 \pm 0,69^{\mathrm{a}}$ & $3,57 \pm 0,14^{\mathrm{b}}$ & $4,77 \pm 0,64^{\mathrm{c}}$ & $\mathrm{P}<0,05$ \\
& & & \\
PBBH pascasapih & $0,09 \pm 0,00^{\mathrm{a}}$ & $0,07 \pm 0,01^{\mathrm{a}}$ & $0,08 \pm 0,01^{\mathrm{a}}$ & $\mathrm{P}>0,05$ \\
$\quad$ absolut (kg) & $0,60 \pm 1,31^{\mathrm{a}}$ & $0,37 \pm 0,01^{\mathrm{b}}$ & $0,43 \pm 0,07^{\mathrm{c}}$ & $\mathrm{P}<0,05$ \\
$\quad$ relatif (\%) &
\end{tabular}

Keterangan: Superskrip yang berbeda pada baris yang sama menunjukkan adanya perbedaan nyata $(\mathrm{P}<0,05)$

\section{Berat Setahunan dan Ukuran-Ukuran Tubuh Umur Setahun}

Rata-rata berat badan dan ukuranukuran tubuh umur setahun terdapat pada Tabel 3. Rata-rata berat setahunan dan ukuran-ukuran tubuh umur setahun kambing BG1 lebih tinggi daripada BG2 namun kedua bangsa silangan tersebut masih lebih tinggi daripada PE. Hal tersebut menunjukkan bahwa performans pertumbuhan kambing BG1 pada saat lahir, sapih, maupun setahun melampaui BG2 maupun PE.

Performans pertumbuhan tertinggi diharapkan terjadi pada BG2 seiring dengan meningkatkan proporsi genetik kambing Boer dalam BG2 yaitu 75\% Boer dan $25 \%$ PE sedangkan BG1 hanya mengandung 50\% Boer dan 50\% PE.

Performans pertumbuhan kambing Boerawa G2 lebih rendah daripada BG1 diduga disebabkan belum stabilnya kambing
BG1 akibat masih adanya pengaruh keragaman genetik non aditif yang terjadi pada BG2 seiring dengan meningkatnya proporsi genetik kambing Boer dalam BG2.

Kambing BG1 dan BG2 merupakan hasil antara dalam pembentukan kambing Saburai secara grading up untuk meningkatkan performans pertumbuhan kambing PE. Hal yang hampir sama dengan penelitian ini dilaporkan pada kambing Boerka-1. Berat badan kambing Boerka-1 umur 9 bulan yang merupakan hasil persilangan antara kambing Boer jantan dengan kambing Kacang betina $(11,34 \pm 2,92 \mathrm{~kg})$ menunjukkan hasil yang tidak berbeda $(\mathrm{P}<0,01)$ dengan kambing Kacang $(10,01 \pm 1,09 \mathrm{~kg})$.

Bobot badan umur 9 bulan kambing Boer $(18,20 \pm 5,93 \mathrm{~kg})$ lebih tinggi daripada Boerka-1 maupun Kacang. Belum tercukupinya pakan pada Boerka-1 mengakibatkan pertumbuhannya tidak optimal (Mahmilia et al., 2007). 


\section{Pertambahan Bobot Badan Harian Absolut dan Relatif}

Data pada Tabel 4 memperlihatkan bahwa pertambahan berat badan harian (PBBH) prasapih dan pascasapih absolut kambing PE tidak menunjukkan perbedaan namun apabila dihitung secara relatif, maka PBBH prasapih dan pascasapih relatif kambing PE tetinggi dan terendah pada BG1. Hal tersebut disebabkan oleh perbedaan berat blahir dan berat sapih yang rendah pada kambing $\mathrm{PE}$ namun $\mathrm{PBBH}$ kambing PE sama dengan BG1 dan BG2, Berat lahir kambing $\mathrm{PE}, \mathrm{BG} 1$, dan $\mathrm{BG} 2$ merupakan penyebut dalam rumus $\mathrm{PBBH}$ relatif sehingga semakin besar berat lahir dan berat sapih maka PBBH relatif semakin kecil apabila pembilangnya sama.

Nilai PBBH absolut ketiga kelompok kambing tersebut relatif sama karena ketiga kelompok tersebut mendapat manajemen pemeliharaan yang sama, antara lain ukuran kandang, kualitas dan kuantitas pakan sehingga pertumbuhan kambing BG1 dan BG2 yang seharusnya melampaui kambing PE tidak tercapai. Hal tersebut juga dilaporkan oleh Mahmilia et al. (2007) pada kambing Boerka-1 (silangan antara Boer jantan dengan Kacang betina) bahwa performans pertumbuhan kambing Boerka-1 masih sama dengan kambing Kacang. Berat badan umur 9 bulan kambing Boerka-1 tidak berbeda dengan kambing Kacang karena belum tercukupinya pakan sehingga pertumbuhannya tidak optimal.

\section{SIMPULAN}

Berdasarkan pembahasan disimpulkan bahwa performans pertumbuhan kambing Boerawa grade 2 belum optimal.

\section{SARAN}

Berdasarkan pembahasan disarankan agar pihak VBC kambing Boerawa di Pekon Dadapan, Kecamatan Sumberejo, Kabupaten Tanggamus, Provinsi Lampung melakukan perbaikan pakan dengan memberikan pakan yang sesuai dengan kebutuhan kambing Boerawa dan melakukan perkawinan interse terlebih dahulu sebelum disilangkan dengan pejantan Boer agar kambing silangan tahap berikutnya memiliki performans yang lebih baik daripada kambing silangan tahap sebelumnya.

\section{DAFTAR PUSTAKA}

Barry, D. M. and R. A. Godke. 2005. The Boer Goat. The Potential for Cross Breeding. Boergoats. Com. Cover Page (Previous Display). Department of Animal Sciences, LSU Agricultural Center. Lousiana State University. Baton Rouge. Lousiana.

Bharathidhasan, A., R. Narayanan, P. Gopu, A. Subramanian, R. Prabakaran, and R. Rajendra. 2009. Effect Non Genetic Factors on Birth Weight, Weaning Weight and Pre weaning Gain of Barbari goat. Tamilnadu. J. Vet. Anim. Sci. 5(3): 99-103.

Dakhlan, A., Sulastri, I. Damayanti, Budiyah, and K. Kristianto. 2009. Does productivity index of boerawa does and etawa grade does fed by traditional and rational foodstuff. Proceeding of The 1st International Seminar on Animal Industry 2009. Faculty of Animal Science, Bogor Agricultural University. pp. 248-262.

Erasmus, J. A. 2000. Adaptation to various environments and resistance to disease of improved Boer goat. Small Rum. Res. 36: 179-187.

Greyling, J. P. C. 2000. Reproduction traits in the Boer goat doe, Small Ruminant Research 36 (2) (2000), pp. 171-177.

Hardjosubroto, W. 1994. Aplikasi Pemuliabiakan Ternak di Lapangan. PT Grasindo. Jakarta.

Kurnianto, E., S. Johari dan H. Kurniawan., 2007. Komponen Ragam Bobot Badan Kambing Peranakan Ettawah di Balai Pembibitan Ternak Kambing Sumberrejo Kabupaten Kendal. Fakultas Peternakan Universitas Diponegoro. Semarang. hal. 236-244.

Leite-Browning, M. L. 2006. Breed Options for Meat Goat Production in Alabama. 
Alabama Cooperative Extension System UNP-84.

Luminto. 2005. Produktivitas Ternak Kambing Peranakan Etawah di Kabupaten Kulonprogo. Skripsi. Fakultas Peternakan Universitas Gadjah Mada. Yogyakarta.

Mahmilia, F., M. Doloksaribu, dan S.Nasution. 2010. Pengaruh faktor non genetik terhadap bobot lahir kambing Boer pada Stasiun Percobaan Loka Penelitian Kambing Potong Sei Putih. Seminar Nasional Teknologi Peternakan dan Veteriner. hal. 477-481.

Mahmilia F., F. A. Pamungkas, dan M. Doloksaribu. 2007. Laju pertumbuhan prasapih dan sapih kambing Boer, Kacang, dan Boerka-1. Dalam: Prosiding Seminar Nasional Teknologi Peternakan dan Veteriner.

Nasich, M. 2011. Produktivitas kambing hasil persilangan antara pejantan Boer dengan induk lokal (PE) periode prasapih. J. Ternak Tropika Vol. 12, No.1. 56-62.

Nurgiartiningsih, V. M. A. , A. Budiarto, G. Ciptadi, T. Joharyani, M. Nasich, and Subagiyo. 2006. Birth weight and litter size of crossbred Boer and local Indonesia goat. Proceeding of the $4^{\text {th }}$ ISTAP Animal Production and Sustainable and Agriculture in the Tropic. Faculty of Animal Science. Gadjah Mada University. November 2006. pp. 422-425.
Shipley, T. and L. Shipley. 2005. Why you should raise Boer goats "Meat for the future". Indonesiaboergoat.com.

Steel, R. G. D. dan J. H. Torrie. 1991. Prinsip dan Prosedur Statistika. Diterjemahkan oleh B. Sumantri. PT Gramedia. Jakarta

Sulastri dan Sumadi. 2004. Estimasi respon seleksi sifat-sifat pertumbuhan dengan metoda seleksi massa pada populasi kambing Peranakan Etawah di Unit Pelaksana Teknis Ternak Singosari, Malang, Jawa Timur. Jurnal Penelitian Pertanian Terapan. Edisi Khusus. Volume IVa. No. 2. Mei 2004. Unit Penelitian dan Pengabdian Kepada Masyarakat Politeknik Pertanian Negeri Bandar Lampung. Bandar Lampung. hal. 157-169.

Sumadi dan S. Prihadi. 1997. Standarisasi kambing Peranakan Etawah bibit di Daerah Istimewa Yogyakarta". Makalah. Sarasehan Standarisasi Kambing PE. Yogyakarta

Thiruvenkadan, A.K., K. Chinnamani, J. Muralidharan, and K. Karunanithi. 2008. Effect Non Genetic Factors on Birth Weight of Mecheri Sheep of India. Livestock Research for Rural Development.

Warwick, E. J., J. M. Astuti, dan W. Hardjosubroto. 1990. Pemuliaan Ternak. Gadjah Mada University Press. Yogyakarta. 